industry. Many of Pioneer's competitors plan their growth so as not to destroy the logic of this umbrella or to provoke retaliation from Pioncer. Pioneer's competitors actually rely upon Pioneer's stabilizing influence on pricing to protect their own margins. However, the high cost of genetic research in the industry aggravates competition. The continual battle for market share requires ever-increasing research expenditures. In turn, increasing sales volume is required to cover these costs. This cycle pushes up competition and raises the costs of competitors, who are contemplating exit.

So the corn-genetics industry is characterized by low threat of entry, relatively weak customers and suppliers, and little threat of sub- stitute products. The intense internal rivalry within the industry keeps seed-corn competitors from becoming more profitable. On balance, the Porter analysis is revealing and correct.

III

George Kidd is president of management consultants Kidd \& Company (Shorewood, WI).

James Dvorak is an associate of Kidd \& Company.

\title{
EU agrees on patents but nixes BST for 5 years
}

The patent directive will likely be ratified. But the BST moratorium could mean a socioeconomic hurdle to European agbiotech product approvals.
OXFORD, U.K. - The European Union (EU, Brussels) is putting out mixed signals as far as biotechnology goes. On the positive side, the EU recently cobbled together an eleventh-hour compromise on its directive on biotech patents, saving the directive from extinction. On the negative side, though, the EU has extended the moratorium on sales of bovine somatotropin (BST) in Europe for the next five years.

Just when it looked like the EU would not get a harmonized patent directive after all, members of the European Parliament (EP, Strasbourg, France) and two parties - the EU's Council of Ministers (CoM), which is made up of ministers from the EU's 12 member nations, and the European Commission (EC), the EU's civil service-managed to strike a deal at a meeting on January 23 , the final deadline for a compromise between the groups. The stumbling block had been the extent to which patents on human body parts would be allowed. Members of the EP wanted the directive to explicitly ban patents on all body parts. The position of the CoM and the EC, however, called for a ban on patents on body parts "as such," a position that would allow patents for cells, genes, and proteins that are isolated from the body.

At the January meeting, the EP members backed down from their hard-line position and accepted the position of the CoM and the EC. Though this will allow patents for cells, genes, and proteins that are isolated from the body, such patents-as a concession to the EP members - will only be awarded for inventions that include "industrially applicable body parts obtained in a technical manner," rather than for the body parts themselves. This lan- guage is somewhat baffling, though, as patents can only be granted if an invention has novelty and has industrial application. So it seems that the interpretation of this language by EP members differs from that by the CoM and the EC.

The EP members also managed to win other concessions. The CoM and the EC agreed to strengthen language in the patent directive on policing gene therapy and animal suffering. They agreed, too, to incorporate into the directive any future EU laws on the rights of farmers to use patented animals for their own use without paying licensing fees.

Unanimity was not achieved, however. Four EP members, as well as Denmark and Luxembourg, remain in opposition to the patent directive. Yet, eventually, the directive will likely be ratified, and all EU member states will then award biotech patents under harmonized conditions. Nonetheless, even once ratified, wrangling over the directive will probably continue, with the debate shifting to a semantic focus on what the directive actually says.

More worrying for the industry, however, is the specter that the BST moratorium presents a socioeconomic hurdle to European agbiotech product approvals. The EU Agricultural Council (AC) - which is made up of farm ministers from EU member states-decided to extend the moratorium on the commercial use of BST until the end of 1999, with only Britain and Denmark voting against the extension. Though the AC attributed its decision to a concern for animal welfare, it seems its real concern was a political one. Farm ministers-whose constituents, particularly in France, include small farmers-are not sure what impact BST will have on the EU's milk-quota system, which seeks to control an EU-wide surplus of milk.

The only concession to BST makers from the $\mathrm{AC}$ is to allow field trials of the hormone to proceed. What is not yet clear is the extent and control of the trials. What has been announced is that EC officials will collect trial results and determine the impact of BST on the health and safety of cows. The $\mathrm{EC}$ will then present to the AC before July 1, 1998 a report on the field trials to allow farm ministers to fully evaluate BST's impact. The AC has stated that milk from BST-treated cows will not be allowed onto the EU market.

Monsanto(St. Louis, MO)—which is trying to win EU approval for its version of BST-is putting the best spin it can on the moratorium, stating that limited trials will boost its case for marketing approval. "Limited utilization of BST will enable the company and the farmers to learn how BST can best be used in the context of the EU milk-quota system," says Monsanto.

The rest of industry, however, is not so taken with the AC decision. The Forum for European Bioindustry Coordination (FEBC, Brussels), a biotech trade association, says that it is concerned by the precedents set by the extension of the BST moratorium, which was due to expire at the end of December, arguing that it creates legal uncertainty for future agbiotech products and that it disregards EU commitments under international trade agreements. It is possible that the moratorium's extension could invite challenges from trading partners against an indirect barrier to trade, since the moratorium will likely prevent the export to the EU of BST-treated products.

-Mike Ward 